\title{
EMBODIMENT, GENDER AND IDENTITY: A STUDY OF VIRGINIA WOOLF'S THREE GUINEAS
}

\author{
Archana Gaur (Ph.D. Student) \\ Department of English and Modern European Languages \\ University of Lucknow, Lucknow, Uttar Pradesh, India.
}

\begin{abstract}
Virginia Woolf's Three Guineas, highlights the themes of profession, war, marriage, education and the response of the writer towards these heads firstly from the perspective of male hegemonic ideology and subsequently moans the discussion towards the female perception. Virginia Woolf considers both the sexes and emphasizes the differences in the manner in which a male, from a patriarchal social order looks at war and a female of the same strata perceive it. She confers the freedom of an educated man's son with the limitation imposed on the daughter of the same educated class man. The writing done by the female writer, on topics, usually associated with the male sex, (on the basis of the hegemonic ideology) creates a new type of ideology that comment on the attributes attached to a body and in what sense the stereotypical notions of prevalent ideology put limits on that body to follow certain set of attributes. The paper explores the distinct perspective of female writer who is trying to present the differences and similarities of both the sexes by comparing their current role in different spheres of social and political framework. The paper seeks for the need of freeing the body of female from the fixed roles attached to it and thus shatters the phallocentric limitations imposed on female sex in context to war, education, marriage and profession.
\end{abstract}

Keywords: Female Body, Marriage, Phallocentric, War, Profession, Ideology.

Women and Language; and the gap between the two, is the matter of social construction that had never been studied or analyzed in a very purposive way. Though women have been writing since times immemorial but they largely subscribed to the language which was phallocentric. Besides Virginia Woolf, other women writers like, Christina Rossetti, Sylvia Plath, Alderine Rich, Nancy Chodorow, Shulamith Firestone, Helene Cixous, Elaine Showalter, Mary Shelly, Mary Wollstonecraft, and, Judith Butler, among others raised their voice to dissent against the phallocentric order and the masculine hegemonic domination. This paper presents the argument in favor of a new tradition of equality which does not circumscribe the choices available to women based on their sexed attributes. Equality to attain freedom to act through the use of linguistic space in the liberal society that constantly consider women as equals but fails at praxis, is what this paper adheres. If at any point the writing by the women got hindered it will be a threat to the practice of linguistic freedom that could help a body of norms to attain freedom to select the attribute for itself by getting out of the clutches of logo centric ideological domination of masculine myth.

Virginia Woolf published her nonfiction book Three Guineas on June 3, 1938 as a sequel to A Room of One's Own. The book's original title was "Professions for Women" and it was intended to be a novel-essay with alternating fiction and nonfiction chapters. Eventually, Virginia separated the fiction and nonfiction sections. The non-fiction section became Three Guineas and the fiction section became her novel The Years. The book is a long essay discussing fascism, war and feminism, tying them all together in a series of letters to various organizations that had requested financial donations from Virginia. In the book titled, Marketing Virginia Woolf: Women, War, and Public Relation in Three Guineas, the writer introduces the book in the following words,

On 2 June 1938 the Hogarth Press published Virginia Woolf's feminist polemic Three Guineas. Like A Room of One's Own, written a decade earlier, Three Guineas is centrally concerned with the material condition of space and economy that govern women's contribution to the public sphere. In contrast to the more hopeful room, which culminates in Woolf's famous exhortation to her women readers to revive the "dead poet who was Shakespeare's sister," Three Guineas is rife with anxieties. Written as Europe drifted towards armed conflict (Woolf was correcting proofs the week Hitler marched into Austria) Three Guineas has a rhetorical urgency quite different from its predecessor: money and a room to write are all very well (Staveley 295).

The epistolary format of the letter ties the issue of war and feminism together. The chapters, highlights the repetitive acceptance of a male voice that had imposed its 


\section{International Journal of Engineering Applied Sciences and Technology, 2021 \\ Vol. 6, Issue 3, ISSN No. 2455-2143, Pages 118-121 \\ Published Online July 2021 in IJEAST (http://www.ijeast.com)}

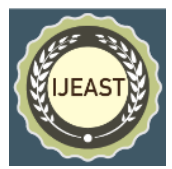

superiority on the hysterics and build a definite set of norms for genders, to follow as the traditional relic. The book is an attempt to shatter those imposed roles attached to female self that they are not allowed to step out of the household boundaries, they could not speak about topics like sex, orgasm, love-making, marriage and pleasures, they could not show their involvement in politics, war and other socioeconomic decision.

Although speaking about the gender roles might sound cliché as it is recrudescent for past many years, but this further compelled me to take interest in the topic as after reaching so far on the path of struggle one must start practicing the treatment of women as equals at ground level. Although literature is getting liberal with the acceptance of writing done against the stereotypical models linguistically, but the minds are still not been able to become secular on this topic of equality and accepting the voices of male and female both as literary texts and not denying female writings for the reason of their sex. Elaine Showalter thus writes, "Women literature must go beyond these scenarios of compromise, madness and deaths. Although reclamation of suffering is the beginning: its purpose is to discover the new world" (Waugh 105). Highlighting the works with feminist approach such as Three Guineas discovers a completely new world of female reality that has always existed but was a victim of oversight.

Virginia Woolf starts her book Three Guineas by laying down the differences in gender by pointing out the perspective of female on the topic of war. Woolf writes, "A letter perhaps unique in the history of human correspondence, since when before has an educated man asked a woman how in her opinion war can be prevented?-Unanswered" (1). The reality of the circumstances prevailing in the age of Virginia Woolf compelled her to put forward such a feminist perspective through the essay. It seems like the author intend to make an attempt for equality and presents one example wherein the female cliché and stereotype of keeping them disconnected with topics such as War, which is considered through ages as a masculine trait and male concern. Writing about men's perspective on war in Three Guineas Virginia Woolf says, "Here, immediately, are three reasons which lead your sex to fight; war is a profession; a source of happiness and excitement; and it is also an outlet for manly qualities, without which men would deteriorate; But that these feelings and opinions are by no means universally held by your sex" (4). Narratives presented the stories of war and bravery always with a man as the center of action. Through those age old tales, our perspectives are constantly shaped in a particular fashion. On the basis of that knowledge society visualizes, 'male' and 'female' in particular set of fixed attributes, that are attached to their body on the basis of their sex. Thus human mind conditioned to fix the body in their respective roles and attributes. Virginia Woolf presented 'war' as the attribute that is stereotypically associated with male sex and with her writing she crushes this stereotypical conditioning of fixed identity and provides flexibility to a body for choosing its own attribute.

Beginning with the idea of war, writer as stated above has emphasized on the importance of this letter in reshaping the views of historical models of society wherein female and male have had different standards. No doubt, they still have differences but the highlight of the present writing is that it's a response on war by a woman, with the purpose to investigate the understanding of the recurring themes of war, profession, education and marriage, from the level of female feminist writer of early nineteenth century.

Virginia Woolf's writing maps out the differences of the gender created with what Laura Mulvey called "Normative Sex" and the repetitive nature of these norms related to labels attached to body on the basis of birth and thus framing it into a particular gender regardless of what it could have been if not treated with confined set of roles or norms of society. Virginia Woolf presents the thin line of division between the male and female sex of the same social background in order to evaluate the position of female in a family of educated male. She also considers the two distinct perspectives formed on the topic of patriotism and the reason she investigates through her work states the problem existing in set pattern of sex roles practiced in a family, attached to the body. Speaking of the girl child, who is denied of all education and on other hand young boys of the same family has all right to get education so he could make career and participate in the matter of nation's political and social sphere. The situations, facilities and freedom of a female are completely different from that of a male (from the same family) in nineteenth century. Pointing out those differences, Virginia Woolf says in Three Guineas,

That is fair general statement of what patriotism means to an educated man and what duties it imposes upon him. But the educated man's sister - what does 'patriotism' mean to her? Has she the same reasons for being proud of England, for loving England, for defending England? Has she been 'greatly blessed' in England? History and biography when questioned would seem to show that her position in the home of freedom has been different from her brother's; and psychology would seem to hint that history is not without its effect upon mind and body. Therefore her interpretation of the word 'patriotism' may well differ from his (21).

Although Virginia Woolf points out the differences in the two sexes on various grounds she did not forget to establish the similarities between them. On the topic of War she says that it was always supposedly men's concern, and because female had no right to use language to disagree with patriarchy so they are also in favor war. She quotes, "No education, no earning, getting more restricted to private houses, if restricted they will exert their influence in favor of 


\section{International Journal of Engineering Applied Sciences and Technology, 2021 \\ Vol. 6, Issue 3, ISSN No. 2455-2143, Pages 118-121 \\ Published Online July 2021 in IJEAST (http://www.ijeast.com)}

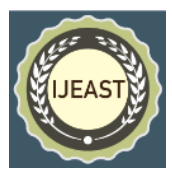

war" (17). Re-evaluating her idea of war for female and male in modern society, she takes into consideration the influence of patriarchy on family and emphasize how ideas related to gender roles since ages were generalized to all. Woolf taking advantage of her linguistic freedom, stresses on nongeneralized part of female psyche and presents the contradictory notion of possibility of exclusion of war from society if women are allowed to take political positions. With all their differences both sexes look at war with the same eye and it has same impact on female as it has on male. Virginia Woolf quotes in her essay Three Guineas about women on war in following words, "War, you say, is an abomination; a barbarity; war must be stopped at whatever cost. And we echo your words. War is an abomination; a barbarity; war must be stopped. For now at last we are looking at the same picture; we are seeing with you the same dead bodies, the same ruined houses" (5).

Hegemonic tendency of masculine myth prevailing in social context limits the consumption of power to only one sex. Since ages women have been denied education, profession and interference in political and economic matter at global and local level. Women were forced to dwell in silence on topic of war, country and politics. Male and female differ from each other physically and biologically; they were constantly shaped to differ ideologically and culturally as well. Male have always been served with different level of nurturing and so their body is trained in certain attributes that matches masculinity. As Helene Cixous calls it 'Castration Complex' that set the manner of Male upbringing while female are the one who are 'Decapitated'. Helene Cixous in her essay Castration or Decapitation? Writes, “. . . she is given images that don't belong to her, and she forces herself, as we've all done, to resemble them" (Waugh 484). The mode of nurturing repetitively framed ideology and traditional narrative taught female to adapt a set of behavior dissimilar to men of the family that further had shunned her right to participate in education, polity and other worldly affairs. The upbringing and lack of opportunities since medieval time for women, made a society that was dominated by male leaders. Focusing on the issue of education, educational institutes and profession of male and female Virginia Woolf in Three Guineas writes,

... for though they establish the value of education, they also prove that education is by no means a positive value; it is not good in all circumstances, and good for all people; it is only good for some people and for some purposes. It is good if it produces a belief in the church, of England; bad if it produces a belief in the Church of Rome; it is good for one sex and for some professions, but bad for another sex and for another profession (14).

The views presented here cover the collective mentality of generation and attitude of the masses on education or war or sole of women and men in society that differs on the basis of gender. As C.T. Mohanty in her famous essay "Under Western Eyes: Feminist Scholarship and Colonial Discourse", quotes, "the sexual division of labor, the family, marriage, household, patriarchy, etc., are often used without their specification in local cultural and historical context. . .In most cases the assigning of task on the basis of sex has an ideological origin" (347). The imprints of ideological differences for genders are still present in the practice of culture and social norms at the level of family and also at workplaces. The freedom to get good education and funds allotment for female education has always been the matter of struggle. Female sex had to fight (suffrage movement and other feminist revolution) in order to get education rights and so it becomes necessary for those who got education that they must fight for the other illiterate female population. Education proved a milestone in providing awareness to society regardless to gender. The male and female with open intellect could evaluate the disastrous nature of cultural norms as it kept female to the margins. As without education a woman has no command on language but with opportunity to educate herself, the society can have awareness for the rights of major section of population that were previously left unnoticed within the walls of house. Virginia Woolf states that educated men's daughter must be educated, if she wants to take her body out of fixed roles and attributes associated to it. The first and most essential requirement for freeing a female self from the patriarchal or the normative way of living is- Education- followed by her indulgence in holding career, money and having right to take decision at sociopolitical level where she is (to some extent) no longer in the grip of fixed set of actions which hindered her growth as an individual.

There are still many, among the masses that are not privileged to get education, get a profession, and hold a career and become a part of politics and socio-economic sphere of country, but the population visible at each level is mostly dominated by male. The women of these strata allow themselves to be influenced by male domination. In the context of India there was an article titled, "India Fall Short in Female Literacy", related to the growth of literacy and the right of education to the female masses. It states the position of India in following words,

India's school education system is underperforming in terms of equality when compared to its neighbors, Pakistan, Bangladesh and Nepal. The research studies changes in female literacy over a number of schooling years. The proportion of women who completed five years of primary schooling in India and were literate was 48 per cent, much less than 92 per cent in Nepal, 74 per cent in Pakistan and 54 per cent in Bangladesh. . . India ranks low in global indices of female literacy as well (The Hindu). 


\section{International Journal of Engineering Applied Sciences and Technology, 2021 \\ Vol. 6, Issue 3, ISSN No. 2455-2143, Pages 118-121 \\ Published Online July 2021 in IJEAST (http://www.ijeast.com)}

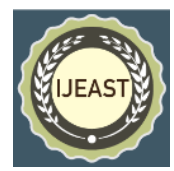

The fact that women had been able to attain a position in the social framework could not be side-lined but still on the basis of the article mentioned above we can get the glimpse of the portion of female population still living in the boundaries of household within the phallocentric order that makes India's ranks $38^{\text {th }}$ among the 51 developing countries. The portion of women who are privileged to attain liberty in sense of action and making decision for her body must use her education for writing down new tradition of dictating her own body, its own strengths and weaknesses and thus create their own space in society in the field of war, education, and politics and join the tradition of earning right of language usage and prove the constructed boundaries of female body as a mere conditioning, as Elaine Showalter in her essay Towards Feminist Poetics while mentioning about the emergence of gynocriticism, quotes,

I shall call this kind of analysis the feminist critique, and like other kinds of critique it is a historically grounded inquiry which probes the ideological assumptions of literary phenomena. Its subjects include the images and stereotypes of women in literature, the omissions and misconceptions about women in criticism, and fissures in male constructed literary history (Waugh 99).

Virginia Woolf proceeds further to discuss the issue of marriage, an age old tradition attached to women. In context of marriage and women she quotes, ". . . And what was the great end and aim of these years, of that education? Marriage, of course. . ' It was not the question of WHETHER we should marry. But simply of whom we should marry', says one of them. It was with the view to marriage that her mind was taught" (Woolf 19). It was served as the main concern for women to get themselves ready for sole purpose of marriage. With the view of marriage that she was taught to preserve her body intact for her husband. Marriage was considered as profession for women, but in the book Three Guineas Virginia Woolf dismantles this practice by posing questions on constructive nature of role fixation in the context of marriage, war, politics and education.

Virginia Woolf asserts on the kind of education an educated man's sister receives at present and thus establishes the rights to change the ideological framework with time. In the feminist tone Virginia Woolf assertively keeps the concepts of war, profession, education and marriage at the core of the text and presents several arguments to prove the line of binaries existing in the phallocentric social framework. It is this quest of linguistic freedom and constant writing that helps dissolve these binaries associated with body. In order to make the minds of the masses liberal one must learn to write liberally without using binaries and so Virginia Woolf through her book Three Guineas states, the importance of education of daughter along with son. The daughter's privilege to have the use of language creates a more liberal linguistic culture that in turn will help the female body gain freedom to act according to its choice without any labels attached.

\section{REFERENCES}

[1] Balibar, E., and Machery. "Literature as an Ideological Form." Modern Literary Theory, edited by Patricia Waugh, Bloomsbury Academic, 04 May 2001. p 61.

[2] Cixous, Helene. "Castration or Decapitation?". Modern Literary Theory, edited by Patricia Waugh, Bloomsbury Academic, 04 May 2001.p 484.

[3] De Beauvoir, Simone. "Introduction." The Second Sex, translated and edited by H.M.Parshley, New York, Alfred A.KNOPF, 1976.

[4] Habib, M.A.R. Modern Literary Criticism and Theory. Blackwell Publishing, Carlton, Australia, 2005.

[5] Mohanty, Chandra Talpade. "Under Western Eyes: Feminist Scholarship and Colonial Discourses". Duke University Press. p 347.

[6] www.google.co.in/url?sa=t\&source=web\&rct=j\&url =http://weldd.org/sites/default/files/Mohanty_Under_ Western_Eyes_240914.pdf\&ved=0ahUKEwisjOri4o TWAhVBpY8KHYXdBukQFggkMAA\&usg=AFQj CNF4ztvAYUdm-lhkbcD04CdllXECbQ

[7] Mulvey, Laura. Visual Pleasure and Narrative Cinema. $1975 . \quad$ pp 6-18. www.jahsonic.com/VPNC.html

[8] Sandefur, Justin. India Falls Short in Female Literacy. The Hindu, New Delhi, October 24, 2016.

[9] www.thehindu.com/data/India-falls-short-in-femaleliteracy/article16080505.ece

[10] Showalter, Elaine. "Towards a Feminist Poetics." Modern Literary Theory, edited by Patricia Waugh, Bloomsbury Academic, 04 May 2001. pp 98-108.

[11] Staveley, Alice. Marketing Virginia Woolf: Women, War, and Public Relation in "Three Guineas." The John Hopkins University Press, Volume 1, 2009. p 295. www.jstor.org/stable/40930548?seq=1\#page_scan_ta b_contents

[12] Woolf, Virginia. Three Guineas. eBooks@ Adelaide, July $15, \quad 2015 . \quad$ pp 01-21. ebooks.adelaide.edu.au/w/woolf/virginia/w91tg/index .html

[13] Woolf, Virginia. "The Diary of Virginia Woolf." The Virginia Woolf Blog, Three Guineas by Virginia Woolf by Rebecca Beatrice Brooks, June 11, 2013. Virginiawoolfblog.com/three-guineas-by-virginiawoolf/ 